\title{
Higher Education In Times Of Financial Distress: The Minnesota Experience
}

\author{
Roger Severns, Minnesota State University, Mankato, USA
}

\begin{abstract}
Like many states, Minnesota has incurred large budget deficits during the past two years. Those deficits have, in turn, led to changes in a number of areas of state government, particularly higher education. Faculty have incurred pay freezes and layoffs, programs have closed, and tuition increased. Campuses within the MnSCU system have been allowed to find their own way in dealing with many of these problems, with the result that some approaches have worked better than others. This paper will chronicle some of the problems encountered and solutions attempted, and will evaluate various strategies used within the system from the perspective the Faculty Association. The intent is to provide insight into identifying preferred strategies when addressing similar situations in the future.
\end{abstract}

Keywords: Minnesota; Higher Education; Financial Distress; Strategies

\section{INTRODUCTION}



ike many states, Minnesota has had a series of budget deficits over the past several years. In Minnesota, those deficits stem from a series of tax cuts in 1999 and 2000 that reduced the income tax rates on all tax brackets and instituted a series of tax breaks that further reduced state income. While legally required to have a balanced budget, since 1999 Minnesota has incurred a series of budget deficits which have been resolved, in part, through the use of:

- $\quad$ funds acquired through a lawsuit involving the tobacco industry

- fee increases

- $\quad$ redirecting dedicated funding resources to other purposes

- $\quad$ use of budget reserves

- $\quad$ federal assistance

- $\quad$ increases in property taxes

- $\quad$ a series of accounting shifts where payments required for one year were pushed into future years

In resolving the most recent state budget deficit, a disagreement between the Legislature and Governor resulted in a 19-day shutdown of state offices. When an agreement was finally reached, it resulted in a $13.5 \%$ reduction in state funding for the state universities, which is expected to be made up through higher tuition and a projected \$1.9 billion deficit for the two-year budget that begins July 1, 2013 (Salisbury, B. 2011, and Fischenich, M., 2011).

While the state has been able to resolve deficits in the short term, the underlying problems have continued to become more difficult to resolve over the years. In addressing these budgetary issues as they pertain to the state university system, some approaches have been local - at the campus level - while others have been state wide, often mandated by either the legislature or system office. The degree of success has varied. 


\section{STATE WIDE APPROACHES}

\section{Tuition and Faculty Pay}

When talking about fiscal problems at the Minnesota state universities, it's quickly apparent that faculty pay and tuition are closely intertwined. Faculty pay comprises about $70 \%$ of all university expenses. State universities essentially have two sources of revenue to pay these and other expenses - funds from the state legislature and tuition. As a result of financial distress at the state level, tuition at the Minnesota State universities, which are a part of the MnSCU system of colleges and universities and are not land grant institutions, has increased sharply since 1999 (Tuition over Time, 2011) . Even though, by state law, tuition is suppose to pay for only onethird of the expense of educating in-state students, tuition has more than doubled over the past decade which has resulted in tuition climbing to over $60 \%$ of revenue for these schools. The most recent state budget reduction, passed in July 2011, will reduce state funding for the MnSCU system below 1997 levels, even though approximately 40\% more students currently attend those institutions than in 1997 (Stanton, R. IFO Action Alert, July 14, 2011).

From 2003-2007, after hard bargaining, the union that represents the Minnesota State universities' faculty (the IFO) negotiated a 2.4\% increase in salary every other year. In the 2007-2009 contract, however, they received an increase of slightly over $8.0 \%$. Then, faced with another state deficit in 2009 , faculty suggested and the state agreed to a two-year freeze on salaries (News Release, 2009).

While attempting to keep expenses down through limiting faculty salaries, MnSCU has learned there really is a degree of competition in hiring and retaining better faculty. As MnSCU faculty salaries have fallen below the $50 \%$ percentile nationally for similar institutions, good young faculty have become more difficult to hire and retain, necessitating a larger pay increase to "catch up" with competing schools.

This staggered approach has resulted in an increase in faculty salaries of approximately $3.6 \%$ per year for returning faculty since 2000 (Master Agreement, 1999; 2011). While salaries have been a result of bargaining and "catching up" with other schools, reoccurring deficits have often meant tuition had to be increased to pay for those increases in salaries. Because funding from the state has not been consistent and increases in faculty salaries has varied, tuition increases have typically been the amount required to fill in the gap between the amount provided by the state and the amount required by the campuses. This has resulted in substantial uncertainty and hardship for students and parents of students attempting to plan financially for a college education at a state university.

Both the legislature and MnSCU are not insensitive to the financial hardships caused by significant tuition increases. They have repeatedly been asked by students and parents to limit tuition increases (Elliott, K., 2011) and the new MnSCU Chancellor, Steven Rosenstone, has said tuition increases should be a "last resort" (Rosenstone, 2011); but given a limited ability to provide additional funds from the state and a limited ability to control expenses, tuition has been the only viable alternative source of funding.

During the budget shortfall of approximately $\$ 2$ billion over the 2009/2010 budget biennium, faculty at the Minnesota State universities agreed to a pay freeze as part of the solution. While the most recent shortfall was larger - $\$ 5$ billion over the 2011/2012 biennium, university faculty were excluded from discussions of a pay freeze. It seems clear that attempts to adjust faculty pay in some counter cyclical manner based on the availability of state funds has not been a success.

\section{Closings/Realignment}

With 32 public colleges and 54 campuses, it has been suggested that one means Minnesota might take in addressing financial distress might be for MnSCU to close one or more campuses (Our View, 2010). While this discussion has concentrated on the smaller community colleges rather than the four-year schools, politically, each campus seems to have enough local support to make closure problematic.

Rather than fighting with legislators to close campuses, MnSCU has begun to look toward increased efficiencies in operations through alignment. One of the smaller, more remote state universities - Bemidji State - has 
been aligned (meaning essentially merged) with Northlands Technical College which is less than two miles away. As a result of this alignment, those students at the technical college can make use of university facilities, including housing, meal plans, the recreation and fitness center, health services, the library, the American Indian Resource Center, clubs, and campus activities. To some extent, the two schools' administrations have also been merged.

The success of the Bemidji experience is debatable. While there may be some greater efficiency due to scale, problems have emerged in philosophy and climate. There are fundamental differences between community colleges, which are oriented toward technical skills and basic instruction, and more academically-oriented Baccalaureate and Graduate degree-granting institutions. Having the two aligned has tended toward a "one-size-fitsall" approach that has irritated faculty and students at both schools.

Even with the problems that have emerged, the Bemidji alignment has been sufficiently successful that another small and remote university - Southwest State - is currently being considered for alignment with the Minnesota West group of community and technical colleges. Members of the IFO Executive Committee discussed the results of realignment at Bemidji and prospects of realignment at other institutions during a meeting of campus faculty union presidents in January 2011. The consensus was that realignment between Southwest State and Minnesota West would be a much more difficult process than in Bemidji, as Minnesota West has five campuses scattered throughout an area slightly larger than that of Rhode Island. Other possibilities for alignment, however, include Mankato, Rochester, St. Cloud, Minneapolis/St. Paul, and Moorhead. Each of these communities have both a state university and either a community or technical college, and alignment continues to be looked at as a possible means of increased operating efficiencies (Executive Committee, personal communication, January, 2011).

\section{Distance Learning}

Another approach to limit expenses tried on a state-wide basis has been the expanded use of distance learning. The idea of distance learning in Minnesota has always been to make it easier for students to attend university classes, particularly if they lived some distance from a state university campus. The thought was that students who would not otherwise attend a state university would then matriculate. Originally, while a limited use of videos sent through the mail was tried, the preferred approach was to send faculty to teach evening classes in surrounding communities. It was thought it would be more efficient to send one faculty member to a remote location than to have a group of students travel to campus.

In the last few years, it's been generally decided that sending individual faculty to remote locations is not efficient, so this approach has been largely abandoned and replaced by two alternatives: 1) remote campuses and 2) web-based instruction. Through the first approach, an entire campus is created separate from the main campus. Numerous classes and, indeed, entire programs may be offered at the remote site. Examples of this are the MSUMankato MBA and nursing programs which are offered both in Mankato and at a new campus in a Minneapolis suburb. Faculty typically travel approximately 75 miles (120 kilometers) to teach at the remote campus, either on an in-load or overload basis and receive additional payment for travel expenses and time.

Both the MBA and nursing programs are offered at a premium price (Minnesota State - Tuition Rates and Fees) and, like the earlier approaches, are intended to consist of students who would presumably not attend a state university if the remote location were not available. The premium price that students pay for these courses is expected to be sufficient to offset the cost of operating the remote site in the long run. However, startup costs have not yet been recovered and it has yet to be determined if this approach will eventually be cost efficient.

The second approach - web-based instruction - is an evolutionary descendent of the old video classroom. It includes the use of both advanced technology, such as Cisco's TelePresence, which allows live face-to face meetings over the internet in a way far advanced over the old classroom video products for small groups, and the use of streaming video for both synchronized and non-synchronous courses. While all of these approaches have proven to be convenient for students and in high demand, the technology required is expensive and it is not yet certain as to whether or not they will be cost effective. 
Like the classes taught at remote locations, an additional fee is charged for classes taught online. Supposedly the additional funds generated by these fees are sufficient to pay for the additional costs engendered by offering these classes, but in part because of accounting irregularities, actual costs and revenues are unclear. When faculty teach in-load, they don't add to the total number of students enrolled and those faculty teaching on an overload basis have to be paid for additional courses on a proportional basis. Online students are supposed to have equal access to student resources, such as the library, databases, and advising. It has not yet been determined how to appropriately allocate the expense for these services to students away from a main campus, particularly those taking courses on an online basis (Robert Hoffman, Minnesota State Mankato Vice-President for Strategic Affairs, personnel communication, March, 2011).

An additional difficulty is the composition of online students. In theory, their numbers should be added to the on-ampus group. This increased student population should, in turn, increase revenues through increased tuition. However, on some campuses, it is believed that as much as $85 \%$ of "online" students take such courses as a substitute for on-campus courses, either because of convenience or an inability to get into the on-campus sections. Because of the way tuition is calculated, this results in a net loss in campus income rather than a gain.

\section{LOCAL APPROACHES}

\section{Restructuring}

Faculty at each of the state universities in Minnesota is composed of three groups: 1) tenured, 2) tenure track, and 3) temporary. Temporary faculty, by contract, is supposed to be hired only for limited purposes and time periods. While proportions vary both by campus and over time, typically $35-40 \%$ of the faculties are composed of temporary workers.

The most recent state budget shortfall was predicted nearly two years in advance. Given this prediction, some campuses began restructuring as soon as they were able. The process of restructuring meant not filling vacant tenure track positions or filling them only with temporary workers. On some campuses, virtually no new tenure track faculty have been hired over the past two years (Executive Committee, personal communication, April, 2011).

While meeting resistance from the faculty union, the current contract allows the administration to hire fixed-term (temporary) faculty for up to four years. Additionally, some artful manipulation occasionally occurs when a temporary worker is employed in another line (technically another position) after their four years is up (Master Agreement).

Those campuses that have not filled tenured and tenure track positions with permanent faculty have had a distinct advantage during the current budget shortfall. They have been able to substantially reduce expenses by reducing staffing and temporary faculty members who have been hired are often paid less than tenure track faculty. However, reduced staffing has also meant larger class sizes and less tuition revenue as the number of students these schools can handle has dropped. Finally, as temporary workers can only be hired for a maximum of four years, and the state faculty union has indicated no willingness to extend this period, this may be a temporary solution (Donald Larsson, Inter Faculty Association President, personal communication, February, 2011).

\section{BESIs}

In an attempt to limit expenses in 2009, the MnSCU Board of Trustees initiated a program known as BESIs (Board Early Separation Incentives). This program allows state universities to offer older faculty early retirement incentives. Under this program, each campus president can choose whether or not to offer such incentives and, if they do utilize them, the president can select specific academia areas to which they apply.

Incentives vary, but typically include health care for up to two years and, in some cases, salary for a year. Incentives must be paid for out of the local campus budget and presumably are only offered in circumstances where cost savings will occur (MnSCU Board Policy 4.11). 
On most campuses that have offered BESIs, two sets of circumstances have been considered: 1) where the retiring faculty member won't be replaced and 2 ) where the retiring faculty member can be replaced by a cheaper (typically younger) faculty.

While some campuses have chosen to not offer BESIs, those that have report substantial success in persuading older faculty to retire early. In circumstances where an older faculty member won't be replaced, campuses have typically been more generous in their incentive offers. Anecdotal evidence suggests faculty in their late fifties and early sixties may be particularly interested in the opportunity to receive health care insurance after retirement.

While there are only a limited number of faculty eligible for early retirement, they are usually more senior and higher paid faculty (Becky Barkmeier, Minnesota State Mankato, Director of Human Resources, personal communication, February, 2011). On a limited basis, persuading these faculty to leave and either not be replaced or be replaced by cheaper faculty, has been a success

\section{Retrenchment}

When a state government deficit leads a campus to be so short of funds, drastic measures must be taken; retrenchment can and has been used. Retrenchment is the layoff of tenured or tenure track faculty "due to system or university budget reductions, budget reallocations, expenditure freezes, or unfunded increases in operating costs, resulting from action by either the Legislature, the Governor, or MnSCU". The faculty contract allows retrenchment following attrition or retraining of faculty for other positions. Retraining occurs when it is determined that a faculty member is no longer needed or can be afforded in their primary area but, with some retraining, may be able to teach effectively in a secondary area, which is still needed by the university (Master Agreement).

Restructuring and BESIs, over the past two years, have resulted in approximately 280 fewer faculty in the MnSCU state universities, but at some schools, the budget was apparently not cut enough and retrenchment was declared. Approximately 20 tenured and tenure track faculty members have received retrenchment notices for next year with about three-quarters of that number from the two largest schools.

By contract, if a position in the system opens that a retrenched faculty member could do, regardless if it's the same thing they had been doing, the retrenched faculty must be rehired into that position. Additionally, any program targeted for retrenchment would be unable to employ temporary faculty for three years. Thus, retrenched faculty members may not be permanently separated from employment within the system. In practice, however, most faculty who are retrenched seek employment anywhere they can find it and rarely return to MnSCU (Donald Larsson, Inter Faculty Association President, personal communication, February, 2011).

Retrenchment is considered a draconian step, to be used only rarely and only in cases of truly critical budgetary situations. It has not been invoked for nearly 30 years prior to this year. That the budgetary shortfall is severe enough this biennium that it has been needed suggests all of the other attempts at dealing with predictable fiscal difficulties by the Minnesota State colleges and universities have failed.

\section{CONCLUSIONS AND PERSPECTIVES OF THE FACULTY UNION}

From the perspective of the faculty association, the inability to manage a predictable budget shortfall without resorting to extreme measures indicates mismanagement of state resources. This mismanagement manifests itself through wildly fluctuating tuition, a reduction in course offerings, courses that may only be offered on an online or remote campus basis, unpredictable faculty salaries, and the layoff of both temporary and tenured faculty.

Financial distress is not an uncommon experience for many states - certainly not for Minnesota. From the perspective of the faculty, however, failing to adequately plan for such an experience is unacceptable. More and better long-term solutions need to be found. 


\section{AUTHOR INFORMATION}

Roger Severns is a Professor of Finance at Minnesota State University, Mankato. He holds a PhD in Finance from the University of Nebraska. Over the past 15 years, he has held a number of positions in the faculty union; most recently, campus Faculty Association President. He has also been a member of both the state faculty association Executive Committee and Board of Directors. E-mail: roger.severns@mnsu.edu.

\section{REFERENCES}

1. Elliott, K. (2011, February 17). Tuition Freeze bill brings out passions. Retrieved from http://www.mndaily.com/2011/02/17/tuition-freeze-bill-brings-out-passions

2. Fischenich, M. (2011, July 19). Local Legislators following party lines on deal. Retrieved from http://mankatofreepress.com/local/x1424065712/Local-legislators-following-party-lines-on-deal

3. Master Agreement, IFO/MnSCU 2009-2011. Retrieved from http://www.ifo.org/

4. $\quad$ Master Agreement(s), IFO/MnSCU 1999-2001. Retrieved from http://www.ifo.org/Negotiations/negpastagreements.htm

5. News Release, MnSCU, 2009. Retrieved from http://www.mnsu.edu/news/read/?id=old1235157139\&paper=topstories.

6. $\quad$ MnSCU Board Policy - Chapter 4 Human Resources. Retrieved from http://www.mnscu.edu/board/policy/411.html

7. Our View: State needs to rethink higher ed. (2010, February 1). The Mankato Free Press. Retrieved from http://mankatofreepress.com/editorials/x1237942133/Our-View-State-needs-to-rethink-higher-ed/print

8. Rosenstone, Steven, (2011, Feburary 2). MnSCU picks Rosenstone as Chancellor-Elect. Retrieved from http://www.deseretnews.com/article/700106602/MnSCU-picks-Rosenstone-as-chancellor-elect.html?pg=2

9. Salisbury, B. (2011, July 24). Minnesota Budget: A closer look at the deal to end the shutdown. Retrieved from http://www.twincities.com/ci_18532719.

10. Tuition over Time, 1999 - 2010 (2011). The Chronicle of Higher Education. Retrieved from http://wiredcampus.chronicle.com/article/Interactive-Tool-Tuition-Over/125043/

11. Tuition Rates \& Fees, Minnesota State University, Mankato (Fall 2011). Retrieved from http://www.mnsu.edu/campushub/tuition_fees/ 